\title{
Polish Students in the Period of COVID-19 Pandemic
}

\author{
Małgorzata Przybysz-Zaremba, and Krzysztof Polok
}

\section{ABSTRACT}

The aim of the article is to present the situation of Polish students during the COVID-19 pandemic. The study, based on the voluntary participation of students, and having a clearly pilot nature was carried out using the selfmade questionnaire consisting of 28 questions, each of them regarding the implementation of the objectives outlined in the study. The study involved 160 full-time and part-time students of state universities embedded in two voivodships with the highest COVID-19 infection rate, i.e. in the Upper Silesia and Mazovia voivodships. Our studies have shown that the COVID19 pandemic time significantly impedes students' education and psychophysical functioning. Over $98 \%$ of students study remotely at universities. The dominant forms of such education were: e-mailing students with ready-to-study materials and tasks for self-implementation, remote learning platforms such as e-university, Microsoft Teams, Zoom, meet, Classroom, Moodle, Click-Meeting, as well as other distant elearning platforms. For security reasons, libraries operating at the universities were also closed, which significantly hindered students from completing the process of remote education, as none of the universities provided a substitute form of using library collections.

Keywords: students, college, university, remote (distant) education, COVID-19 virus

\author{
Published Online: March 29, 2021 \\ ISSN: $2736-4534$ \\ DOI: $10.24018 /$ ejedu.2021.2.2.71 \\ Małgorzata Przybysz-Zaremba \\ State University of I. Mościcki in \\ Ciechanów, Poland \\ (email: malgorzata.p_z@interia.pl)
}

\section{Krzysztof Polok*}

University of Bielsko-Biala in Bielsko Biala, Poland

(e-mail: sworntran@interia.pl)

*Corresponding Author

\section{INTRODUCTION}

In connection with the epidemiological situation in Poland caused by the COVID-19 virus, from March 12th, 2020, teaching at universities was suspended. Since then, the implementation of the education process has changed - the form of that has been adopted was the one of remote education. As there is no name systematization here the names also used here are: distance education, remote education, electronic education, e-education, e-learning, computer-assisted teaching, digital education [1], [2], [3], [4], [5]. The very concept of remote education is very broad and can apply to both e-learning and teaching via correspondence sent by traditional mail or by sending instructions during a telephone conversation [4]. Nowadays, remote learning usually takes place with the help of a number of (mostly Internet-based) information technologies (further: IT). The specificity of such education lies in the proper selection and adaptation to the recipients of appropriate working methods, while achieving the objectives of education. In general, adults who prefer giving methods, such as: multimedia presentation, (mini) lecture, and/or materials for independent study contained in the sent files, leave the conscious recipient the greatest possible field for their reflection and time for conscious internalization of acquired knowledge [6].
Therefore, remote education requires participants to learn independently, study, interact and, at the same time, be effective, which in the case of university students is revealed in the form of final credit for the given (currently studied) subject. Thus, the effectiveness of remote education depends on the student's approach and commitment to independent study and the selection of appropriate technical tools made by the teacher. Educational platforms offer a very wide range of different tools used in counseling and for direct contact between lecturers and students. Unfortunately, this is not personal contact, intense and emotionally colored, which are important in supporting the participant (student). Lack of real and direct contact often causes a decrease in motivation to work [6]. In addition, the current epidemiological situation in the country caused by the occurrence of the COVID-19 virus, which is experienced not only by students, but also all of us, is not conducive to psychophysical development, and even more so the effectiveness of participation in remote education. In the latest publication published in Poland, titled Education during the COVID-19 virus pandemic. With a distance from what we are currently doing as teachers, Jacek Pyżalski [7] describes how the development of a pandemic has disorganized everyday life and human functioning. He refers to the crisis, recognized as a break in the life line, as a result of an event that hinders the achievement of life goals. 
That obstacle is COVID-19, which evokes strong emotions, fear and anxiety - impossible to be overcome with the help of the conventional methods. The actions we are currently able to undertake mainly concern various preventive measures aimed at protecting against COVID-19 infection. One of the key protective forms is social isolation, which, having a longterm dimension, will not have a positive impact on human psychophysical functioning.

\section{Methodological ASSUMPTIONS}

The general purpose of the study was to check how Polish students are doing during the COVID-19 pandemic. Referring to the general purpose constructed in this way, the following research problems were posed:

1) How does education take place at universities in Poland? Are students satisfied with it?

2) What forms of help do universities offer their students?

3) How do students function physically and mentally? What kind of activities do they take to improve this functioning?

4) What preventive actions are taken by universities and students to protect themselves against the COVID-19 virus?

The study was conducted based on the self-designed questionnaire, which was prepared for students in connection with the COVID-19 pandemic situation. The survey questionnaire consisted of 28 questions about education at the university in the face of the COVID-19 pandemic; possibilities of help and support for students proposed by the university in which they study; the functioning of students in mental and physical terms and the actions taken by them to improve this functioning; as well as preventive actions taken by the universities and the students themselves to protect health and life against COVID - 19.

The study involved 160 full-time students (134 people $(83.2 \%)$ and part-time (26 people $(16.2 \%)$ of several state universities embedded in two significant provinces: Upper Silesia, 93 people (58.1\%); and Mazovia, 67 people (41.9\%). In these provinces, the coronavirus infection rate is the highest and amounts to: Upper Silesia - 1514 people, Mazovia - 2030 people - as of April 21, 2020. Among the respondents there were 138 women $(86.3 \%)$ and 22 men $(13.8 \%)$. as follows: 19 years - 4 students $(2.5 \%), 20$ years 20 students $(12.5 \%), 21$ years - 21 students $(13.1 \%), 22$ years - 38 students $(23.8 \%), 23$ years - 31 students (19.4\%), 24 years and more - 46 students $(28.7 \%)$. There were 113 (70.6\%) undergraduate students and $47(29.4 \%)$ were masters students; 47 (29.4\%) first-year students; 47 (29.4) \%) second year students; $41(25.5 \%)$ - third year students, 10 $(6.3 \%)$ - fourth year students, $15(9.4 \%)$ - fifth year students.

The respondents studied in the following fields: English philology - 79 students (49.3\%), pedagogy - 51 students (31.9\%), economy - 7 students $(4.4 \%)$, speech therapy - 12 students $(7.5 \%)$, social work - 11 students $(6.9 \%)$. The selection of the sample for the research consisted in sending a survey to students of the universities with which the authors of the text cooperate. The students were asked to fill out a questionnaire voluntarily and assured that the survey was anonymous. Only willing and interested students participated in the study. The statistical analysis was performed using the Statistica 13.1 statistical package. However, due to time constraints and the "novelty" of the studied problem, i.e. the COVID-19 pandemic, which is experienced by almost the whole world, our assumption is to present the situation as in the times of the COVID-19 virus pandemic Polish students carry out education at universities; how they function physically and mentally in this very difficult period for us all. This research is only an outline of a problem that will be continued and developed in the near future. The study was conducted at the beginning of April 2020.

\section{ANALYSIS AND DISCUSSION OF THE RESEARCH RESULTS}

According to the announcement of sanitary institutions responsible for state security and in consultation with the Minister of Higher Education from March 12th, 2020 until April 26th 2020 (currently), education at universities is implemented through the so-called distance learning. 158 $(98.8 \%)$ students indicated that the university in which they study provides them with remote education, and only 3 $(1.9 \%)$ stated that this form of education has not yet been taken at the university in which they study. In most universities, however, this form of education takes on a different dimension. The research shows that the dominant form of education is the use of electronic mail (e-mail) to send materials to students - $149(93.1 \%)$ people gave such an answer (Chart 1). The respondents also pointed to the use of social messengers, such as Skype $(15.6 \%$, or 25 people), or Messenger (13.1\%, or 21 people). 112 (70\%) students indicated that they use the distance learning platforms offered by the University. These are: e-university, Microsoft Teams, Zoom, Meet, Classroom, Moodle, Click-Meeting, or elearning platform. In a few cases, the lecturers record the lectures and make them available to students on YouTube.

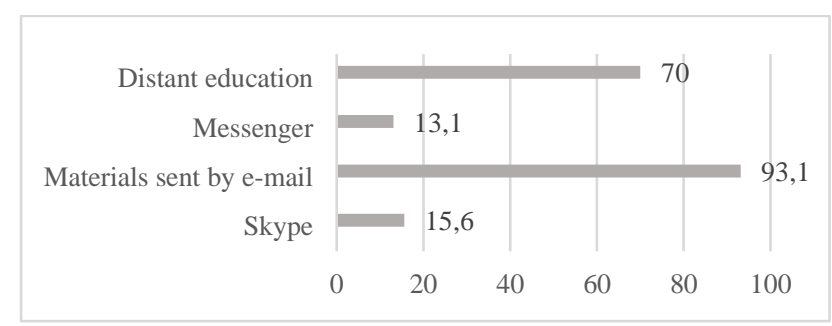

Fig. 1: Forms of distant learning implemented by the universities (in \%) Own elaboration

As one can see, the dominant form of education at Polish universities is equipping students with ready-made materials in accordance with the topical course syllabus. It is worth considering whether this type of education is expected by the students from the lecturers. Despite the fact that $77(48.1 \%)$ students indicated that they are satisfied with the forms of education proposed by the university, a large group of students (34 people, or 21.2\%) are not satisfied with this form of education and 49 of them $(30.6 \%)$ are not fully satisfied. Some students have spoken on the proposed forms of study as follows:

What lecturers do is they mostly send e-mails; only one teacher conducts a lecture on an e-learning platform weekly;

The amount of assignments sent by professors is so huge that I and my friends are forced to sit on laptops for days; we have no time to relax;

They keep sending e-mails in style: 'Here you have tasks, think for yourself and I will check later for a grade';

What I am weekly doing are a dozen or so assignments that take up most of the time every day. I try to do all of them, fulfill my goals, participate in classes using on-line means, 
familiarize myself with the materials, subject literature and do my homework on time. I'm almost off my head at times.

In addition, $128(80 \%)$ students indicated that they could not choose the form of distance education at the university in which they study. According to students' statements, this is not the form of education they expected from the university nor its lecturers. As one can see, students are overloaded with the tasks ordered (sent) by lecturers. We think that all the students in Poland, as well as in other countries, including lecturers and professors, were surprised by the situation that arose as a result of the development of the COVID-19 pandemic. Universities were not fully prepared to implement remote education, and lecturers choose such its forms, which do not require too much time to prepare for the classes, are the easiest to use. It is worth noting that in addition to sending materials to students, lecturers are expected to conduct individual consultations using Messenger, Skype and also use their own telephone to support, give advice and/or help students in need. This seems to be the form of contact most expected by students. Some universities also allow students to contact a psychologist (35 people, or $21.87 \%$ ) or a pedagogue ( 8 people, or $5 \%$ ). Unfortunately, this form of contact with a specialist is carried out remotely, mainly via email, and rarely using Messenger or Skype. 117 students (73.1\%) indicated that their universities did not take any whatsoever action to enable contact with specialists, which would significantly support their mental functioning.

We do not know much about the COVID-19 virus. The media keep informing us about the current and up-to-date statistics, the number of people infected with the virus, and how many deaths there are. Due to security obligations, the State authorities are constantly calling for staying at home and introducing newer and new bans and restrictions. This type of information does not have a positive effect on mental well-being, and lack of exercise, especially for people who need to stay at home, also for physical health. The analysis of the conducted research showed that students care about both mental and physical health (Table 1). The most frequently undertaken activities related to caring for mental health included: listening to music and reading books, while those related to caring for physical health: physical activity (exercises), dancing at home and outdoor walks. Few students undertake other activities that support their mental and physical health. These are: watching TV (mainly movies), relaxing in the open air in the garden, being with family/with children and/or undertaking such activities as children expect from them, e.g. playing board games, drawing. In the case of care for physical health, students pointed to: healthy eating, drinking a lot of warm water, practicing yoga, running outdoors. There are, however, some students who do not care about their mental and physical health and are unable to cope with the coronavirus pandemic situation themselves. Studies have shown that $157(98.1 \%)$ students do not use any form of help and support offered by the university where they study. In this situation, it can be presumed that after the pandemic ends, some students will find it very difficult to return to normal functioning in social reality.
TABLE 1: TYPES OF ACTIVITIES UNDERTAKEN BY STUDENTS IN THE FIELD OF CARE FOR MENTAL AND PHYSICAL HEALTH DURING THE COVID19 PANDEMIC. (OWN ELABORATION)

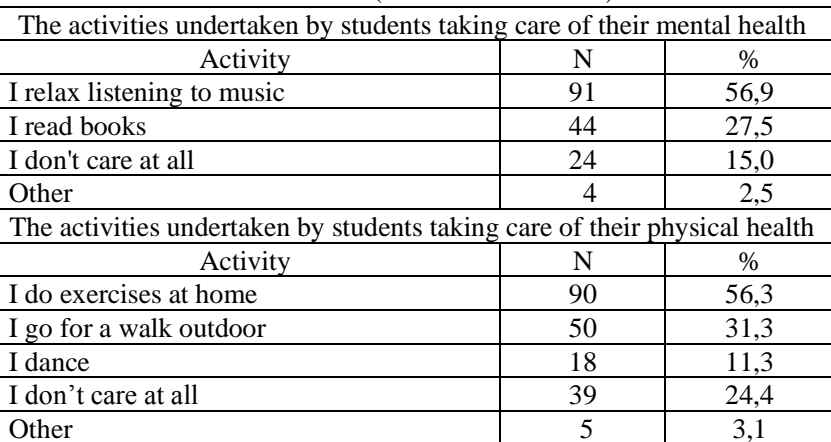

REMARK: The interest does not add up to 100.00 because students had the opportunity to choose several answers.

The analysis of the conducted research shows that the activities undertaken by students in the area of caring for mental and physical health are not always safe in relation to the ongoing COVID-19 pandemic. The students indicated that, for example, they run outdoors or go for a walk. Pursuant to the current restrictions announced by the State authorities, such activities pose a great threat to COVID-19 infection and are currently prohibited. Students take preventive measures against infection with this virus; most often it is the use of disinfectants (147 students, or 91.9\%), the use of gloves (118 students, or $73.8 \%$ ) and masks while shopping (67 students, or $41.9 \%$ ), taking vitamins ( 67 students, or $41.9 \%$ ), proper nutrition (67 students, or $41.9 \%$ ). Students also limit leaving the house, contact with other people (apart from their immediate family, with whom they live), they often wash their hands with disinfectants, if they have to go out shopping they keep a distance of 2 meters from people in the queue.

They comply with WHO recommendations and messages issued by the State Authorities. Also, the universities in which they study have undertaken preventive measures related to providing security for students, lecturers and other administrative employees during the COVID-19 pandemic. One of the key actions taken in this respect was the university lockdown; few universities went even further and suspended all classes (including remote ones). Students can contact the university by phone or e-mail only. In addition to closing the university, the libraries operating at the university have also been closed, which unfortunately poses many problems to students. The implementation of distance education requires them to study independently, reading the books and/or various scientific publications indicated by lecturers. Many students also prepare their MA or BA theses. Thus, closing the libraries significantly hinders their preparation. As it seems, this kind of decision was not the best one; on the one hand, attention was paid to protecting the health and life of students while adopting and implementing remote education, on the other, however, as shown by the research, such education is mainly based on e-mail-based equipping the students with materials for self-study and commissioning tasks to complete. When adopting such a remote form of education, students were not offered a substitute form of using library resources, e.g. online access to the library collections, which should be treated as a kind of hindrance on the part of the university to implement the processes of their education. 


\section{CONCLUSIONS}

The analysis of the conducted research showed that the COVID-19 pandemic time significantly hinders students' education at the university and their psychophysical functioning. The following conclusions come from the studies:

1) over $98 \%$ of students indicated that the university in which they study provided them with remote education, which allows them to carry out their education without any downtime. The dominant forms of distance education were: e-mail-based equipping the students with materials and tasks, the implementation of which consumed a significant amount of their free time; using remote teaching platforms and instant messengers, such as Skype and Messenger. The proposed forms of distance learning were not fully accepted and satisfactory for all students. Most of the students $(80 \%)$ did not have the option to choose the form of distance learning;

2) students take care of their mental and physical health and take various actions to improve it, e.g. they exercise at home, go out for a walk, run, eat properly, relax a lot, watch TV and read. However, not all of the actions taken are safe (e.g. running outdoors can pose a serious threat to COVID-19 infection). When leaving the house for shopping, students take all precautions that the appropriate sanitary and State services recommend (they wear gloves, use disinfectants and wear a mask);

3) some universities provided students with specialist help and support, such as contact with a psychologist or pedagogue. Unfortunately, few of them use this form of assistance;

4) most universities take preventive actions related to ensuring health and life safety for students, lecturers and other administrative staff. All universities in Poland have been closed and can be contacted by phone or e-mail. Libraries operating at universities were also closed, which significantly hindered students from fulfilling the tasks assigned by lecturers and preparing their MA and BA theses. None of the universities has provided a substitute form that would give students the opportunity to access scientific collections.

Summing up, the COVID-19 pandemic time is difficult for all of us. Lack of sufficient information supported by scientific research, as well as statistics constantly cited by the media regarding the number of people infected with this virus, including the number of deaths cause that the feelings of apprehension and fear increase. Students agree on all forms of education and do not analyze them through the prism of the "right" and "wrong" forms. Both the universities and the lecturers employed in them were not fully prepared for such developments. Decisions taken in the country related to the lockdown of the university and the complete transition to distance learning, appeared almost overnight. Nobody predicted this situation. However, to meet the needs of students, they are enabled to contact individual consultations using Skype and Messenger messengers and offer specialist help of a psychologist or pedagogue.

\section{REFERENCES}

[1] M. J. Kubiak, "Szkoła, Internet, Intranet. Wirtualna edukacja” [Eng.: School, Internet, Intranet. Virtual Education]. Wyd. MIKOM. Warszawa 2000.

[2] M. G. Moore, M. M. Thompson et al., The Effects of Distance Learning: A Summary of The Literature. Research Monograph No. 2. University Park, PA: The Pensylvania State University, American Center for the Study of Distance Education, 1990.

[3] S. L. Watson, W. R. Watson, "An Argument for Clarity. What Are Learning Management Systems, What Are They Not, and What Should They Become?", TechTrends, no 51(2), 2007, pp. 28-34.

[4] M. Hołowiecki, "Wykorzystanie e-learningu jako formy kształcenia zdalnego na publicznych uczelniach wyższych w Polsce" [Eng.: The use of e-learning as a form of distance education at public universities in Poland], Lingua Lingua ac Communitas, vol. 24, 2014, pp. 185-206.

[5] M. Plebańska, "Cyfrowa edukacja-potencjał, procesy, modele" [Eng.: Digital education - potential, processes, models], in: Edukacja w czasach pandemii wirusa COVID-19. Z dystansem o tym, co robimy obecnie jako nauczyciele, [Eng.: Education during the COVID-19 pandemic; or what we are currently doing as teachers] (eds.) J. Pyżalski, EduAkcja, Warszawa 2020, pp. 37-42.

[6] E. Lubina, Konstruktywistyczne i behawioralne aspekty kształcenia zdalnego. [Eng.: Constructivist and behavioral aspects of distance learning], E-mentor, no. 1 (8), 2005; http://www.ementor.edu.pl/mobi/artykul/index/numer/8/id/111 [accessed: 21.04.2020]

[7] W. Poleszak, J. Pyżalski, "Psychologiczna sytuacja dzieci i młodzieży w dobie epidemii" [Eng.: Psychological situation of children and youth in the age of epidemics], in: Edukacja w czasach pandemii wirusa COVID-19. Z dystansem o tym, co robimy obecnie jako nauczyciele, [Eng.: Education during the COVID-19 pandemic; or what we are currently doing as teachers] (eds.) J. Pyżalski, EduAkcja, Warszawa 2020 , pp. 7-15.

Małgorzata Przybysz-Zaremba, University professor, dr hab. social sciences in the field of pedagogy. Pedagogue, social educator, Oligophrenopedagogue. Research interests are rooted in social pedagogy, rehabilitation pedagogy, special pedagogy and difficult problems of the family, children and youth, incl. aggression and violence, risky behavior, behavioral disorders, suicidal behavior, alcohol problem (in the family), social maladjustment, addictions and special educational needs, etc. These problems are analyzed in the diagnostic, preventive and supportive (therapeutic) context. The author (and co-author) of about 200 pieces in the city center, including 5 monographs edited by an academic and 44 publications in a foreign language. Participant of about 100 city center centers with foreign capital (Germany, Czech Republic, Lithuania, Slovakia, Ukraine, Latvia), international and nationwide. Participant and scholarship holder of internships (including Italy 2019, 2018; Slovakia 2018; Lithuania 2016) and integration participants in the Erasmus and Erasmus + programs (Italy 2019, 2018; Lithuania 2018, 2017, 2016, 2015, 2013). ORCID: http://orcid.org/0000-0003-2542-5104.

Krzysztof Polok, University professor Hab. Doctor in the field of language education employed at the University of Bielsko-Biala.

His research interests are rooted in the area of creative design of FL lessons in respect to preschool - high school learners. Author of about 200 articles published in Polish and international journals and more than ten monographs published in Poland the United Kingdom, Slovakia and the USA. ORCID: http://orcid.org/0000-0002-0283-9665। 